\title{
Histopathological and Clinical Features of Phyllodes Tumor in Hasan Sadikin Hospital during 2012 - 2016
}

\author{
Natasha A Harsas*, Birgitta M Dewayani**, Raden Yohana*** \\ *Faculty of Medicine Padjadjaran University \\ **Department of Anatomical Pathology \\ Faculty of Medicine Padjadjaran University - Dr. Hasan Sadikin General Hospital \\ ***Department of Surgical Oncology \\ Faculty of Medicine Padjadjaran University - Dr. Hasan Sadikin General Hospital \\ Jl. Prof. Eyckman No. 38, Bandung, 40161 \\ Email:natasha_harsas@yahoo.com
}

\begin{abstract}
Phyllodes tumor is a breast fibroepithelial lesion that rarely occurs. This type of tumor has a tendency to recur and metastasize. This study aims to determine the features of phyllodes tumor in Hasan Sadikin General Hospital in the period of 2012 to 2016, histopathologically and clinically. A descriptive study with cross sectional design was conducted in the Department of Pathological Anatomy, Hasan Sadikin General Hospital, Bandung, from September 2016 to May 2017. Using total sampling, the secondary data is taken from medical records with the diagnosis of phyllodes tumor. From the 88 samples taken, the mean age of the tumor occurrence is 45.56 years old and the mean size of tumor diameter is $10.98 \mathrm{~cm}$. Tumor with a benign type has the highest prevalence, with 54 cases reported. Mastectomy is the most common procedure performed for this tumor. There are 7 recurred patients and 1 patient with metastasis. As a conclusion, it is found out that phyllodes tumor is a rare tumor. In Hasan Sadikin Hospital, it mostly occurs in women aged 45 years with a the benign type. Mastectomy is often performed as a choice of surgical treatment.
\end{abstract}

Keywords : breast tumor, phyllodes tumor, fibroepithelial lesion, local recurrence 


\title{
Gambaran Tumor Phyllodes secara Histopatologis dan Klinis di Rumah Sakit Hasan Sadikin selama Periode 2012 - 2016
}

\author{
Natasha A Harsas*, Birgitta M Dewayani**, Raden Yohana*** \\ *Fakultas Kedokteran Universitas Padjadjaran \\ ***Departemen Patologi Anatomi \\ Fakultas Kedokteran Universitas Padjadjaran - Rumah Sakit Hasan Sadikin \\ ****Departemen Bedah Onkologi \\ Fakultas Kedokteran Universitas Padjadjaran - Rumah Sakit Hasan Sadikin \\ J1. Prof. Eyckman No. 38, Bandung, 40161 \\ Email : natasha_harsas@yahoo.com
}

\begin{abstract}
Abstrak
Tumor phyllodes merupakan salah satu jenis lesi fibroepitel di payudara yang jarang terjadi. Tumor ini memiliki kecenderungan untuk terjadi rekurensi dan metastasis. Tujuan penelitian ini adalah untuk mengetahui gambaran histopatologis dan klinis tumor phyllodes di Rumah Sakit Hasan Sadikin, selama periode 2012 - 2016. Penelitian deskriptif dengan desain cross sectional ini dilakukan di Departemen Patologi Anatomi, RSHS, Bandung dari September 2016 hingga Mei 2017. Sampel yang digunakan adalah total sampling dengan menggunakan data sekunder yang berasal dari rekam medis dengan diagnosis tumor phyllodes. Dari 88 sampel yang diambil, usia rata - rata terjadinya tumor ini adalah 45,56 tahun dengan rata - rata diameter tumor $10,98 \mathrm{~cm}$. Tumor dengan derajat ringan memiliki angka prevalensi tertinggi, yaitu sebanyak 54 kasus. Mastektomi merupakan terapi yang paling sering dilakukan untuk tumor ini. Terdapat 7 kasus rekurensi dan 1 kasus metastasis. Kesimpulannya, tumor phyllodes merupakan tumor yang jarang terjadi. Di Rumah Sakit Hasan Sadikin, tumor ini paling sering muncul pada wanita berusia 45 tahun dengan derajat ringan. Mastektomi merupakan pilihan tindakan operatif yang paling sering dilakukan.
\end{abstract}

Kata kunci : tumor payudara, tumor phyllodes, lesi fibroepitel, rekurensi lokal 
Research Article

\section{Introduction}

Phyllodes tumor is a breast fibroepithelial lesion that rarely occurred. This lesion consists of two components, epithelial and stromal cells. The incidence rate is only $0.3-2.5 \%$ of primary tumors, $2.5 \%$ of fibroepithelial lesions in the breast and $0.5 \%$ of all breast malignancies. ${ }^{1,2}$ Phyllodes tumor occurs mostly in women aged 40 to 50 years old. In Asia, it is common in women aged 25 to 30 years old. ${ }^{3}$

The cause of this tumor remains uncertain. Macroscopically, this tumor has a white consistency and a surface of lobes. ${ }^{4}$ If viewed using a microscope, will appear as a hypercellular stroma with two layers of epithelial surrounding it (Figure 1). These two components form a structure called leaf-like papillary (phyllodes). ${ }^{5,6}$
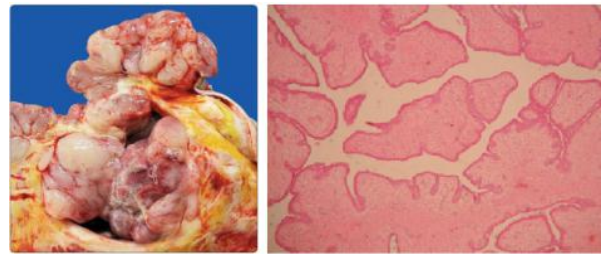

\section{Figure 1 Macroscopic and Microscopic Features of Phyllodes Tumor}

Based on WHO classification in 2012, phyllodes tumor is classified into benign, borderline, and malignant. These three classes are divided based on degrees of stromal pleomorphism (cellularity and atypia), mitotic activity, excessive stromal growth, and tumor boundaries (Table 1). ${ }^{3,5,8}$ The benign type has the highest incidence rate. ${ }^{9}$

Table 1 Classification of Phyllodes Tumor based on WHO 2012 Recommendation $^{3,5,8}$

\begin{tabular}{cccc}
\hline Histopathological Features & Benign & Borderline & Malignant \\
\hline Stromal cellularity & Mild & Moderate & Marked \\
Stromal atypia & Mild & Moderate & Marked \\
Mitotic activity (per 10 HPF) & $<5$ & $5-9$ & $\geq 10$ \\
Stromal overgrowth & Absent & Absent or focal & Present \\
Tumor border & Marked & Marked or focal infiltration & Infiltrative
\end{tabular}

To get an accurate diagnosis, it needs to be diagnosed both preoperatively and postoperatively. The choice of surgical treatment is based on its histopathological 
examination's result. ${ }^{8}$ Wide local excision and mastectomy is the primary choice for its surgical treatment. ${ }^{2,4}$

Phyllodes tumor has high risk of recurrence even in the benign type. It could metastasize to another organ even though it is infrequent. Inadequate surgical margin clearance contribute to these risks. ${ }^{3,10,11}$ Patient's quality of life could be lowered because of the increase in the duration of follow up treatment and monitoring.

Even it is rare, phyllodes tumor is one type of breast tumor that needs to be concerned. The objective of the present study is to determine the histopathological and clinical features of phyllodes tumor in Hasan Sadikin General Hospital as well as its recurrence and metastasis.

\section{Methods}

This cross sectional study is carried out in Department of Pathological Anatomy, Hasan Sadikin General Hospital, Bandung, Indonesia. Using the total sampling technique from secondary data, all data are collected from patient's medical records. Ethical approval is obtained from the Ethical Committee of Health Research, Faculty of Medicine, Padjadjaran University Number 481/UN6.C.10/PN/2017

Patients medical records with diagnosis of phyllodes tumor from 2012 to 2016 recorded in Department of Pathological Anatomy were reviewed. We collected clinical and histopathological data included age, classification based on WHO 2012, type of surgical procedures, histopathological techniques, surgical margin, recurrence status, and metastasis.

\section{Results}

We collected 115 cases of phyllodes tumor in this study period. In total, 27 data are excluded due to its incomplete information. The mean age of the sample population is 45.56 years old and all of them are women. The median age is 44 years old (Table 2).

Based on the clinical data obtained, the most common type of surgical procedure performed is mastectomy (39 cases; 44.32\%), followed by 28 cases with incisional biopsy (31.81\%), 13 cases with wide local excision (14.77\%), and 8 cases with excisional biopsy $(9.09 \%)$. Of the 88 samples taken, 7 patients enrolled as recurrent patient (7.95\%) and 1 patient had metastases (1.13\%) (Table 2). 
Table 2 Age, Surgical procedure, Recurrence status, and Metastasis in Patients of Phyllodes Tumor in Hasan Sadikin

\begin{tabular}{llc}
\hline \multicolumn{1}{c}{ Variable } & Frequency & $\begin{array}{c}\text { Percentage } \\
(\%)\end{array}$ \\
\hline Age & Mean & \\
$\bullet \quad$ Median & 45.56 & \\
• & 28 & \\
\hline Surgical Procedure & 8 & 31.81 \\
$\bullet \quad$ Incisional biopsy & 13 & 9.09 \\
$\bullet \quad$ Excisional biopsy & 39 & 14.77 \\
$\bullet \quad$ Wide local excision & 7 & 44.32 \\
$\bullet \quad$ Mastectomy & 1 & 7.95 \\
\hline Recurrence status & & 1.13 \\
\hline Metastasis &
\end{tabular}

Details of histopathological data can be seen in Table 3. The mean tumor diameter is $10.98 \mathrm{~cm}$ with the median $9 \mathrm{~cm}$. The majority of tumors occurred is benign type (54 cases; $61.35 \%$ ) and followed by 34 cases of malignant type (38.65\%). There are 82 cases identified by the paraffin block (93.18\%) and by frozen section for the rest 6 cases $(6.62 \%)$. The surgical margin data resulted from the histopathological examination showed there are 18 cases $(20.45 \%)$ with positive result and 70 cases with negative $(79.55 \%)$.

Table 3 Histopathological Data of Phyllodes Tumor Patients in Hasan Sadikin

\begin{tabular}{lcc}
\hline \multicolumn{1}{c}{ Variable } & Frequency & Percentage (\%) \\
\hline $\begin{array}{c}\text { Size }(\mathrm{cm}) \\
\text { - Mean }\end{array}$ & $\begin{array}{c}10.98 \mathrm{~cm} \\
9 \mathrm{~cm}\end{array}$ \\
• Median & & \\
\hline Classification & 54 & 61.36 \\
• Benign & 34 & 38.63 \\
- Malignant & & \\
Histopathological technique & 82 & 93.18 \\
- Paraffin block & 6 & 6.82 \\
- Frozen section & & \\
Surgical margin & 18 & 20.45 \\
- Positive & 70 & 79.55 \\
- Negative &
\end{tabular}

The presenting tumors mainly have large size and varied in different ages and in each class. In the benign type, one patient has a big sized lump reaching $29 \mathrm{~cm}$ in diameter. This is also 
Research Article

showed in the diameter variation in different ages and classes in Hasan Sadikin Hospital that are shown in Table 4.

\section{Table 4 The Variation of Size in Benign and Malignant Phyllodes Tumor in Hasan Sadikin Hospital}

\begin{tabular}{|c|c|c|c|c|c|c|c|}
\hline \multirow[b]{2}{*}{ Classification } & \multicolumn{7}{|c|}{ Diameter of Tumor $(\mathbf{c m})$} \\
\hline & $<5$ & $5-10$ & $10,1-15$ & $15,1-20$ & $20,1-25$ & $25,1-30$ & $\begin{array}{l}\text { Total } \\
\text { Cases }\end{array}$ \\
\hline Benign & 21 & 13 & 2 & 11 & 4 & 2 & 54 \\
\hline Malignant & 10 & 5 & 5 & 10 & 3 & 2 & 34 \\
\hline
\end{tabular}

\section{Discussion}

In Indonesia, breast tumor was in the second most prevalence tumor in 2013, following the cervix cancer. ${ }^{12}$ Existing literature stated one of one hundred thousand women had phyllodes tumor. ${ }^{4}$ In previous study that was conducted in the Department of Pathological Anatomy, Hasan Sadikin General Hospital, in period of 2011 to 2014, there were 64 cases of phyllodes tumor reported with the mean age of 40.11 years old. ${ }^{13}$ The age range obtained in this study is $12-72$ years old. This showed increasing in number of incidence and patients' mean age in phyllodes tumor cases in Hasan Sadikin. This is likely due to increased public awareness of the importance of health and with the use of BPJS (Badan Penyelenggara Jaminan Sosial), an inssurance held by Indonesian government, which increase health accessibility.

Phyllodes tumor tends to have large size, it presents as a lump $>2 \mathrm{~cm}$ in diameter and can reach $>10 \mathrm{~cm}$ in diameter. ${ }^{4,8}$ This is proved in the results of this research that shows the mean diameter is $10.98 \mathrm{~cm}$. The size of the tumor is not associated with the histopathological class. $^{9,14}$

There are only 2 classes used in this study, they are benign and malignant. This is due to the availability of the data, the borderline class has no clear boundaries and is classified into malignant. Benign type is mostly occurs with the proportion of $61.36 \%$ of the total cases reported. This has the same result with another study. ${ }^{1,13}$ The benign type has characteristics of mild stromal cellularity, mild atypia, mitotic activity $<5$ per $10 \mathrm{HPF}$, and marked tumor border. $^{3,5,8}$ 
The type of the surgical treatment performed is determined by the characteristic of patient's tumor. ${ }^{8,15}$ There are 10 cases reported which undergo biopsy in Hasan Sadikin as preoperative diagnosis. The rest had been done at the referring hospital. Mastectomy is the most common surgery performed as treatment for phyllodes tumor in Hasan Sadikin. While a hospital in Udupi district, India, often do the wide local excision as a treatment. ${ }^{1}$ This finding is probably due to the large tumor size and its high risk of local recurrence. Mastectomy is also performed if the results of lumpectomy estimated poorly in terms of cosmetics. ${ }^{16,17}$

Frozen section is proved to have similar sensitivity with paraffin block, which is known as the gold standard for histopathological examination. This embedding technique can help surgeon to make a fast decision about how big the surgery is and also reduce the needs of re-operation. ${ }^{15,18}$ In Hasan Sadikin only few cases of phyllodes tumor identified by frozen section. The histopathological data shows there are 18 cases that have insufficient surgical margin. This finding includes in one of the factor involved in contributing the progression of recurrence and metastasis. These can occur in all type of classes and malignant type is at the highest risk. ${ }^{3,10,11}$ The other factor contributing is due to the absence of preoperative diagnosis. ${ }^{1}$

Local recurrence is usually occurred two years after therapy and the tendency is $21 \%$ of cases. ${ }^{3}$ In Hasan Sadikin there are seven patients had recurrence status but none of them has the previous histopathological records. In this study period, there is no recurring patient recorded in Department of Pathological Anatomy, Hasan Sadikin. Metastasis is noted in one patient with malignant phyllodes tumor. This 45 -year-old woman had her tumor being spread to local lymph nodes. In Hasan Sadikin general hospital, follow-up after therapy is routinely performed every month in the first year after surgery and every 3 months in the following year. The prognostic factors of phyllodes tumor may probably associated with histopathological features of the tumor. ${ }^{8}$ Many studies had conducted to determine which histologic features could be used as predictive factors for the prognosis of the patient. ${ }^{8,10,19}$ The benefit of this study may provide references to clinicians in determining therapy for phyllodes tumor, which, as recommended for mastectomy based on indications of phyllodes tumor characteristics. It also can increase public awareness, especially for women aged 40 s by providing an overview about phyllodes tumor. The limitations of this study are the limited data because it only comes from a single data source. 


\section{Research Article}

\section{Conclusion}

Phyllodes tumor is a rare tumor. In Hasan Sadikin general hospital, it mostly occurs in women aged 45 years old in the benign type. Mastectomy is often performed as a choice of surgical treatment.

\section{References}

1. Rajendra B, Tubachi P, Prabhu R, Shenoy R. Phyllodes Tumor - A Clinicopathological Study. IOSR Journal of Dental and Med Sci. 2016;15(3):33-7.

2. Moutte A, Chopin N, Faure C, Beurrier F, Ho Quoc C, Guinaudeau F, et al. Surgical Management of Benign and Borderline Phyllodes Tumors of the Breast. Breast J. 2016;22(5):1-6.

3. Tavassoli F a, Schnitt SJ, Hoefler H, Boecker W, Rosai J, Heywang-Kobrunner SH, et al. Pathology and Getics of Tumours of the Breast and Female Genital Organs. 4th ed. Tavassoli F a, Schnitt SJ, Hoefler H, Boecker W, Rosai J, Heywang-Kobrunner SH, et al., editors. World Health Organization Classification of Tumours. Lyon: International Agency for Research on Cancer Press; 2003.p 100-103.

4. Mishra SP, Tiwary SK, Mishra M, Khanna AK. Phyllodes tumor of breast: a review article. ISRN Surg. 2013;18.

5. Panda KM. A Clinicopathological Study of Benign Phyllodes Tumour of Breast with Emphasis on Unusual Features. J Clin Diagnostic Res. 2016;10(7):14-7.

6. Badwe RA, Kataria K, Srivastava A. Surgical Resection of Phyllodes Tumour: a Radical Approach as a Safeguard Against Local Recurrence. Indian J Surg. 2015;77(2):161-3.

7. Lester S, Hicks D. Diagnostic Pathology: Breast. 2nd ed. Hicks D, Lester S, editors. Amirsys. Elsevier; 2016.p.264

8. Wei J, Tan YT, Cai YC, Yuan ZY, Yang D, Wang S Sen, et al. Predictive factors for the local recurrence and distant metastasis of phyllodes tumors of the breast: A retrospective analysis of 192 cases at a single center. Chin J Cancer. 2014;33(10):492-500.

9. Zhang Y, Kleer CG. Phyllodes tumor of the breast histopathologic features, differential diagnosis, and molecular/genetic updates. Arch Pathol Lab Med. 2016;140(7):665-71.

10. Taira N, Takabatake D, Aogi K, Ohsumi S, Takashima S, Nishimura R, et al. Phyllodes tumor of the breast: Stromal overgrowth and histological classification are useful prognosis-predictive factors for local recurrence in patients with a positive surgical margin. Jpn J Clin Oncol. 2007;37(10):730-6.

11. Amer A, Ainley P, Thompson R, Mathers H. Postoperative follow-up practice of phyllodes tumour in the UK: Results from a national survey. Surg. 2016;16:1-8.

12. Kementrian Kesehatan RI Pusat Data dan Informasi Kesehatan. Stop Kanker. infodatin-Kanker. 2015; hal 3.

13. Quzwain F, Effendi YS, Suryawati B, Parwati I. Imunoekspresi ER- $\alpha$, PR, Wnt5a, dan HMGA2 pada berbagai gradasi tumor Filodes payudara. Imunoekspresi ER- $\alpha$, PR, Wnt5a, dan HMGA2 pada Berbagai Gradasi Tumor Filodes Payudara. Glob Med Health Comm. 2016; 4(2): 93-103

14. Venter AC, Roşca E, Daina LG, Muţiu G, Pirte AN, Rahotă D. Phyllodes tumor: Diagnostic imaging and histopathology findings. Rom J Morphol Embryol. 2015;56(4):1397-402.

15. Association of Breast Surgery at Baso 2009. Surgical guidelines for the management of breast cancer. Eur J Surg Oncol. 2009;35:S8-11.

16. Borhani-Khomani K, Talman M-LM, Kroman N, Tvedskov TF. Risk of Local Recurrence of Benign and Borderline Phyllodes Tumors: A Danish Population-Based Retrospective Study. Ann Surg Oncol. 2016;23(5):1543-8.

17. The American Society of Breast Surgeons. Performance and Practical Guidelines for Mastectomy [database on the Internet]. 2014 [cited 2017 Jan 5]. Available from: https://www.breastsurgeons.org/statements/guidelines/PerformancePracticeGuidelines_Mastectomy.pdf

18. National Cancer Institute [database on the Internet]. 2010 [cited 2017 Jan 8] Pathology Reports. Available from: https://www.cancer.gov/about-cancer/diagnosis-staging/diagnosis/pathology-reports-fact-sheet

19. Tan BY, Acs G, Apple SK, Badve S, Bleiweiss IJ, Brogi E, et al. Phyllodes tumours of the breast: A consensus review. Histopathology. 2016;68(1):5-21. 